\title{
The influence of bio-depolymer fuel components on the exhaust emissions from diesel engines
}

The authors present the results of own research on the application of biofuels and depolymers and their mixtures with diesel fuel and the influence of this type of fueling on the exhaust emissions against standard fuel.

The authors have observed that the application of bio-depolymer fuel $(B I O+D E P) / 20$ does not deteriorate the engine operating parameters particularly in medium engine loads and speeds. The reduction of the PM emission generated by the diesel engines caused by the investigated bio-components and fuel depolymers occurs due to a reduction of the share of the INSOL fraction in the total mass of the emitted PM. The change in the combustion process when fueled with $(B I O+D E P) / 20$ (caused by the compensative influence of the viscosity, density and an increase in CN in particular) also results in a reduction of the exhaust emissions of the outstanding exhaust components.

Key words: diesel engine, exhaust emissions, bio-depolymer fuels

\section{Wpływ bio-depolimerowych komponentów paliwowych na emisję substancji toksycznych z silnika o zapłonie samoczynnym}

\begin{abstract}
Przedstawiono wyniki własnych badań silnikowych nad zastosowaniem biopaliwa i depolimeru oraz ich mieszanin z olejem napędowym jako paliwa do silnika o ZS, a także wplyw tego typu zasilania na emisję substancji toksycznych w porównaniu do emisji przy zasilaniu paliwem standardowym.

Stwierdzono, że zastosowanie paliwa bio-depolimerowego $(B I O+D E P) / 20$ nie pogarsza parametrów eksploatacyjnych silnika, zwłaszcza w zakresie średnich obciażeń i prędkości obrotowych. Ograniczenie poziomu emisji czastek stałych w spalinach silnika o ZS przez badane biokomponenty i depolimery paliwowe odbywa się prawdopodobnie głównie dzięki redukcji udziatu frakcji nierozpuszczalnej INSOL w catkowitej masie emitowanych czastek statych. Zmiana procesu spalania przy zasilaniu paliwem $(B I O+D E P) / 20$ (przez kompensacyjny wpływ lepkości i gęstości a zwłaszcza wzrost LC) powoduje również ograniczenie emisji pozostałych, toksycznych składników spalin.
\end{abstract}

Słowa kluczowe: silnik ZS, emisja spalin, paliwo bio-depolmerowe

\section{Introduction}

In recent years actions have been taken to implement fuels other than diesel fuel for diesel engine applications. These fuels come from renewable sources and their main advantage is lower toxicity of their combustion products.

Unconventional fuels may be applied for diesel engines in a liquid (most frequently vegetable oil esters $[1,8,9,11$, $12]$ ) and gaseous forms (propane-butane, natural gas and biogas [3]).

An unconventional fuel gaining much recognition is the oil fraction that comes from the depolymerization of waste plastic. The use of depolymers as fuel gains in importance as it is not only the question of fueling but also disposal of unwanted waste material.

Waste plastics due to their high resistance to natural biodegradability are becoming one of the fundamental ecological problems of the modern world. Attempts are made to resolve the issue by a destructive processing of such waste into hydrocarbon fraction of wide boiling temperature range with the aim to use it as biocomponent of diesel fuel $[2,4$, 6]. Most of the methods consist in recovering of the energy from the polymer waste by its decomposition into compounds of low molecular mass through catalytic cracking or pyrolysis $[2,4-7,10]$. Thermal or catalytic processes,

\section{Wprowadzenie}

W ostatnich latach podjęto szerokie działania nad wprowadzeniem do praktycznego zastosowania w silnikach o ZS paliw innych niż oleje napędowe. Paliwa te pochodzą ze źródeł odnawialnych, a ich główną zaletą jest mniejsza szkodliwość produktów ich spalania w silniku dla środowiska naturalnego.

Jako paliwa niekonwencjonalne do silników o ZS mogą być stosowane produkty ciekłe, najczęściej estry olejów roślinnych $[1,8,9,11,12]$, a także gazy: propan-butan, gaz ziemny i biogaz [3].

Paliwem niekonwencjonalnym, zdobywającym coraz większe uznanie jest frakcja olejowa pochodząca z depolimeryzacji odpadowych tworzyw sztucznych. Zastosowanie depolimerów jako paliwa nabiera dużego znaczenia, ponieważ oprócz tego, że mogą być źródłem energii - rozwiązują również problem utylizacji uciążliwych dla środowiska odpadów.

Odpady z tworzyw sztucznych ze względu na dużą odporność na naturalną degradację stają się jednym z podstawowych problemów ekologicznych współczesnego środowiska. Próbuje się rozwiązać problem przez destrukcyjne przetwarzanie takich odpadów we frakcję węglowodorową o szerokim zakresie temperatury wrzenia z możliwością zastosowania jako komponentu paliw silnikowych i opałowych $[2,4,6]$. Większość metod polega na odzyskiwaniu energii 
as a result of a decomposition of multi particle polymers, generate compounds of lower molecular mass. The most advantageous seems processing of the olefin plastics (not containing heteroatoms), which provides the possibility of obtaining hydrocarbon fractions of similar properties as those obtained from the processing of crude oil [2]. One of the important advantages of this type of depolymers is that they are not contaminated with compounds whose combustion has an adverse effect on the natural environment (sulfur, chlorine and nitrogen compounds).

\section{Methodology of research}

The authors have conducted their own experimental research consisting in determination of the influence of the composed fuels on the emission of PM, nitric oxides, carbon monoxide and unburned hydrocarbons in diesel exhaust gas.

As the source of the PM the authors used a diesel engine AD3.152 on an engine test bed as shown in Fig. 1, whose exhaust system was fitted with an exhaust sample uptake system (for PM separator and nitric oxides analyzer) and the hydrocarbons and carbon monoxide analyzer probe. For the tests the authors chose an engine of an older generation, as there exists a common opinion [11] that the best effects in the reduction of the exhaust emissions when fueled with RME are obtained in this type of engines.

The measurement of the PM was carried out (based on separated, gravimetrically determined mass of PM) according to programmable, 13-phase tests ECE R-49 through a PM PTP-2000 separator with a dilution micro tunnel (by Pierburg).

For the measurement of nitric oxides the authors used chemoluminescent analyzer (CLD-2000 by Pierburg) utiliz-

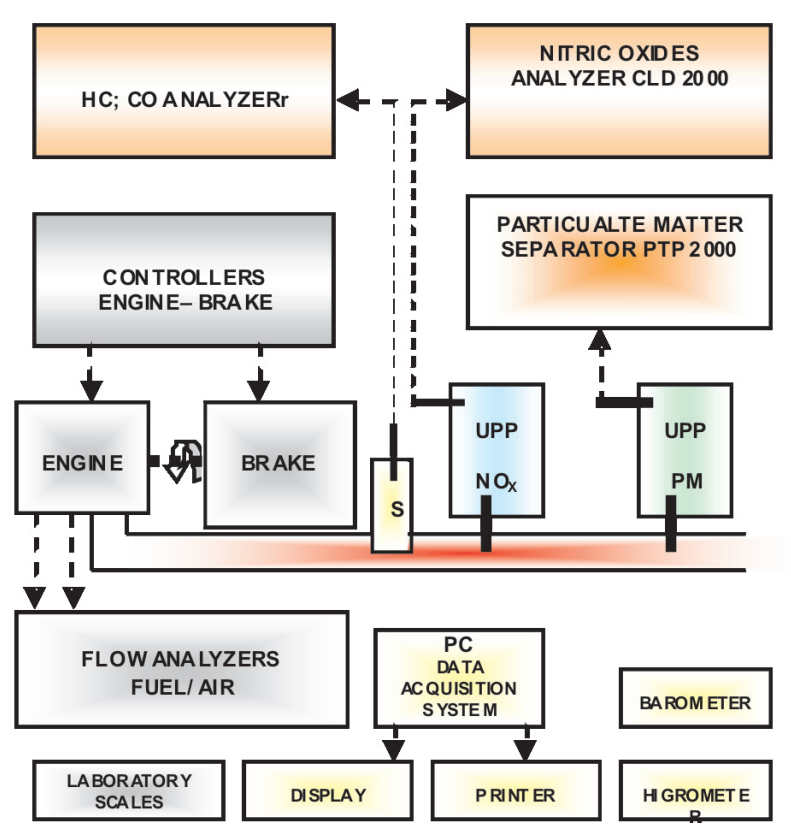

Fig. 1. Layout of the test stand, where: $\mathrm{S}-\mathrm{HC}$ and $\mathrm{CO}$ analyzer probe, $\mathrm{UPP}-\mathrm{NO}_{\mathrm{x}}$ and PM sample uptake system

Rys. 1. Schemat stanowiska badawczego, gdzie: $S$ - sonda analizatora HC i CO, UPP - uktady poboru próbek $N O$ i PM z odpadów polimerowych poprzez ich rozkład do związków o niskiej masie cząsteczkowej na drodze krakingu katalitycznego lub pirolizy $[2,4-7,10]$. Procesy termiczne lub katalityczne na skutek rozpadu wielkocząsteczkowych polimerów generują związki o mniejszej masie cząsteczkowej. Najbardziej korzystne wydaje się przetwarzanie olefinowych tworzyw sztucznych (niezawierających heteroatomów), dzięki czemu można otrzymywać frakcje węglowodorowe o podobnych właściwościach jak frakcje uzyskiwane $\mathrm{z}$ przerobu ropy naftowej [2]. Jedną z istotnych zalet tego typu depolimerów jest to, że pozbawione są zanieczyszczeń związkami, których spalanie niekorzystnie wpływa na środowisko naturalne (związki siarki, chloru, azotu).

\section{Metodyka badań}

Przeprowadzono własne badania eksperymentalne polegające na określeniu wpływu komponowanych paliw na poziom emisji cząstek stałych PM, tlenków azotu, tlenku węgla i niespalonych węglowodorów z silnika o ZS.

Jako źródła emisji cząstek stałych użyto silnika o zapłonie samoczynnym AD3.152 pracującego w układzie hamownianym prezentowanym na rys. 1, którego układ wylotowy wyposażono w układy poboru próbek spalin (do separatora cząstek stałych i analizatora tlenków azotu) oraz sondę analizatora węglowodorów i tlenku węgla. Do badań wybrano silnik o starszej konstrukcji, ponieważ istnieje opinia [11], że największe efekty w ograniczeniu emisji toksycznych składników spalin przy zasilaniu RME uzyskuje się w tego typu silnikach.

Pomiaru emisji cząstek stałych dokonywano (na podstawie separowanej masy cząstek określanej metodą grawimetryczną) zgodnie z programowanymi, 13-fazowymi testami badawczymi ECE R-49 za pomocą separatora cząstek stałych PTP-2000 z mikrotunelem rozcieńczającym (firmy Pierburg).

Do pomiarów tlenków azotu użyto analizatora chemiluminescencyjnego CLD-2000 (firmy Pierburg), wykorzystującego zjawisko emisji promieniowania elektromagnetycznego towarzyszące reakcji tlenku azotu z ozonem.

Do pomiarów stężeń węglowodorów i tlenku węgla w spalinach wykorzystano analizator typu FTIR, model Gastester MHD-218 (firmy Hermann). Niepewność prezentowanych w artykule wyników była następująca: $\mathrm{PM}_{\mathrm{i}} \mathrm{NO}_{\mathrm{x}}$ $<1 \%$, $\mathrm{HC}$ i $\mathrm{CO}<3 \%$.

Do badań użyto komponentów paliw o charakterystycznych cechach podanych w tabeli 1 . Przyjęto nomenklaturę w opisie wyników badań w postaci np. B20 (oznaczającą 20-procentowy objętościowy udział biokomponentu - estru metylowego - w mieszaninie z olejem napędowym), DEP20 (20-procentowy objętościowy udział depolimeru w mieszaninie $\mathrm{z}$ olejem napędowym) itd.

\section{Paliwa z dodatkiem biokomponentu (RME)}

Na rysunku 2 przedstawiono wyniki badań zmiany emisji toksycznych składników spalin w teście 13-fazowym, powodowane różnym udziałem procentowym biokomponentu (RME) w mieszaninie z olejem napędowym. Dla porównania naniesiono poziomy emisji uzyskane dla czystego oleju napędowego (linie przerywane). 
ing the emission of electromagnetic radiation accompanying the chemical reaction of nitrogen oxide with ozone.

For the measurement of hydrocarbons and carbon monoxide FTIR analyzer (Gastester MHD-218 by Hermann) was used. The uncertainty of the results presented in the paper was as follows: $\mathrm{PM}$ and $\mathrm{NO}_{\mathrm{x}}<1 \%, \mathrm{HC}$ and $\mathrm{CO}<3 \%$.

For the tests the authors used fuel components of characteristic features given in table 1 . The following research description nomenclature has been adopted: B20 (20\% volumetric share of a biocomponent-methyl ester - mixed with diesel fuel), DEP20 (20\% volumetric share of depolymer mixed with diesel fuel) etc.

\section{Fuels containing biocomponents (RME)}

Figure 2 presents the results of the tests on the change of the exhaust emissions in the 13-phase tests caused by different percentage share of the biocomponent (RME) in the mixture with diesel fuel. For comparison, the levels of emissions obtained for pure diesel fuel were overlain (dotted lines).

The obtained results hint the following conclusions:

- the least advantageous for the emission of PM and CO turn out to be B5 to B15 fuels ( $5 \%$ to $15 \%$ of the volumetric share of the biocomponents in the fuel). In this range the emission of PM and $\mathrm{CO}$ is growing - for B5 the maximum growth in the emission of $\mathrm{PM}$ reached $13 \%$ and for $\mathrm{B} 15$ the maximum growth in the emission of $\mathrm{CO}$ reached $10 \%$,

- the B5 to B15 fuels are at the same time the most advantageous in terms of the emission of $\mathrm{NO}_{x}-$ exclusively for this range (change in the percentage share of the biocomponent in the fuel) a reduction in the emissions of nitric oxides was recorded - for B10 the maximum reduction was $9 \%$,

- the emission of $\mathrm{HC}$ lowers as the volumetric share of the biocomponent in the fuel grows and for the mixture above B20 the reduction is proportional to the volumetric share of the biocomponent in the fuel. The lowest HC emission was observed for B100 - emission reduction by $39 \%$,

- the greatest reduction of the emission of $\mathrm{HC}(39 \%), \mathrm{CO}$ (24\%) and PM (19\%) was obtained for B100 that was also responsible for a growth in the emission of $\mathrm{NO}_{\mathrm{x}}$ by $9 \%$.

From the operational point of view the most advantageous seems the B20 fuel for which lower levels of emission of all exhaust components were observed as compared to those obtained for diesel fuel at negligible changes of the engine operating parameters ( $\mathrm{M}, \mathrm{N}, \mathrm{g}_{\mathrm{e}}-\mathrm{Fig}$. 3).

The B50 fuel also seems characteristic as the growth in excess of $50 \%$ of the volumetric share of the biocomponent in the fuel leads to a weakening of the trend of emission reduction of $\mathrm{PM}, \mathrm{HC}$ and $\mathrm{CO}$ and also slight increments of the emission of nitric oxides.

For fuels higher than $\mathrm{B} 30$ the nature of the $\mathrm{NO}_{\mathrm{x}}$ emission changes radically. The fuel atomization $(\mathrm{B}>30)$ is realized in a different way than it is realized for diesel fuel (due to differences in the viscosity of both fuels - for B $>30$ the
Table 1. Selected parameters of the fuel components

Tabela 1. Wybrane parametry paliw użytych do komponentów paliwowych

\begin{tabular}{|c|l|c|c|c|}
\hline Item & $\begin{array}{l}\text { Parameters/ } \\
\text { parametry }\end{array}$ & $\begin{array}{c}\text { ON } \\
\text { PN-EN 590 }\end{array}$ & $\begin{array}{c}\text { B100 } \\
\text { RME }\end{array}$ & $\begin{array}{c}\text { DEP100 } \\
\text { DEPOLYMER }\end{array}$ \\
\hline 1 & $\begin{array}{l}\text { Cetane number/licz- } \\
\text { ba cetanowa }\end{array}$ & 51.4 & 51.8 & 77.1 \\
\hline 2 & $\begin{array}{l}\text { Density in the tem- } \\
\text { perature of } / \text { gestość } w \\
\text { temp. } 15^{\circ} \mathrm{C} \mathrm{g} / \mathrm{cm}^{3}\end{array}$ & 835.4 & 882 & 807 \\
\hline 3 & $\begin{array}{l}\text { Viscosity in the tem- } \\
\text { perature of } / \text { lepkość } \\
\text { w temp. } 40^{\circ} \mathrm{C} \mathrm{mm}^{2} / \mathrm{s}\end{array}$ & 2.64 & 5.2 & 3.5 \\
\hline 4 & $\begin{array}{l}\text { Sulfur content } / z a- \\
\text { wartość siarki } \mathrm{mg} / \mathrm{kg}\end{array}$ & 59 & 0.01 & 0.01 \\
\hline 5 & $\begin{array}{l}\text { Calorific value } / \text { war }- \\
\text { tość opalowa } \mathrm{MJ} / \mathrm{kg}\end{array}$ & 42.8 & 38.5 & 41.3 \\
\hline
\end{tabular}

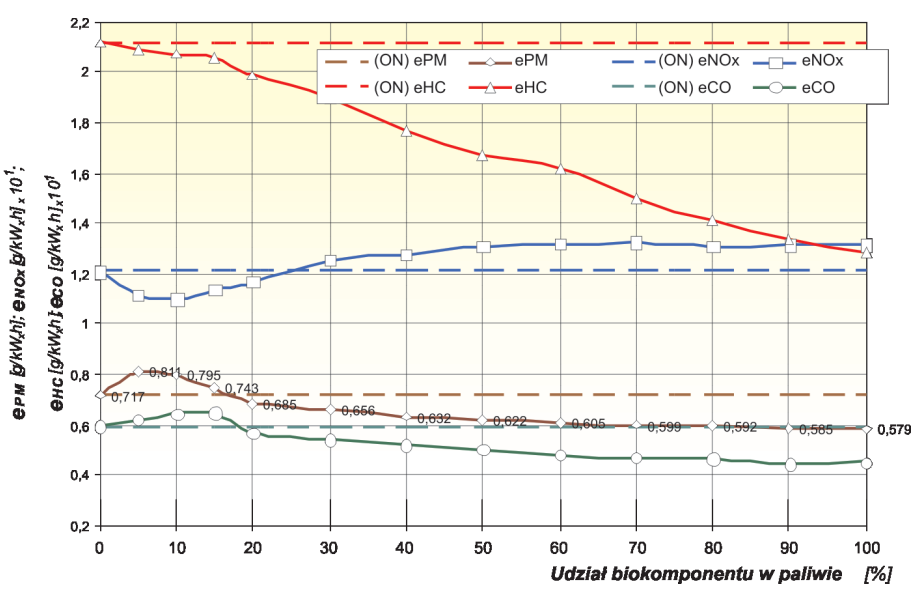

Fig. 2. Changes in the engine emissions (13-phase) caused by different shares of the biocomponent in the mixture with diesel fuel

Rys. 2. Zmiany emisji silnika (test 13-fazowy) spowodowane różnym udziałem biokomponentu $w$ mieszaninie z olejem napędowym

Uzyskane wyniki nasuwają następujące spostrzeżenia:

- najmniej korzystnym dla emisji PM i CO okazują się paliwa B5 do B15 (5 \% do $15 \%$ objętościowego udziału biokomponentu w paliwie), bowiem w tym zakresie emisje PM i CO wykazują tendencję wzrostową, dla B5 wystąpił maksymalny wzrost emisji PM o 13\%, a dla B15 maksymalny wzrost emisji CO o $10 \%$,

- paliwa B5 do B15 są jednocześnie najbardziej korzystne pod względem emisji $\mathrm{NO}_{\mathrm{x}}$ - jedynie dla tego zakresu (zmian udziału procentowego biokomponentu w oleju napędowym) zanotowano redukcję emisji tlenków azotu - dla B10 maksymalna redukcja o $9 \%$,

- emisja HC zmniejsza się ze wzrostem objętościowego udziału procentowego biokomponentu w paliwie, a dla mieszanek powyżej B20 zmniejszenie jest proporcjonalne do objętościowego udziału procentowego biokomponentu w paliwie, najmniejszą emisję $\mathrm{HC}$ zaobserwowano dla B100 - zmniejszenie emisji o $39 \%$,

- największe redukcje emisji HC (39\%), CO (24\%) i PM (19\%) uzyskano dla paliwa B100, przy użyciu którego zanotowano również największy wzrost emisji $\mathrm{NO}_{\mathrm{x}}$ o $9 \%$. Z eksploatacyjnego punktu widzenia najkorzystniejsze 
share of the fuel of double viscosity grows significantly) and it leads to a growth of the local combustion temperatures and facilitates the emission of nitric oxides (Fig. 2). Most likely, higher combustion temperature (increase in the exhaust gas temperature was observed) results in the primary soot being burned in the combustion chamber, which, at a simultaneous release of $\mathrm{HC}$ from the particulate matter (increase in the emission), results that the physical adsorption on the surface - secondary soot - is significantly limited. This is a quantitative (a lower amount of adsorber - secondary soot - and the adsorbed substances) and a qualitative limitation (limitation of the cyclization of the polyacetylene compounds that after dehydrogenization take a form of polycyclic aromatic hydrocarbons and heavy hydrocarbons. Most likely, higher cycle temperatures prevent the liquid phase from solidifying and release the gaseous phase of the PM earlier while active oxygen has the ability to oxidize hydrocarbons not only in the mass of the exhaust gas but also in the PM alone.

Table 2 presents the percentage changes in the emission (as compared to diesel fuel, where: „+" denotes an increase, and ,-,, a decrease in the emission) for selected biocomponent fuels.

From the data (selected fuels) presented on the engine operating characteristics (Fig. 3) it results that for B20 (as compared to $\mathrm{ON}$ ) the increase in the specific fuel consumption and the drop in the engine power output and torque are miniscule (several per cent). The engine parameters significantly deteriorate for B50 - the drop in the engine power output and torque reaches $8 \%$ to $10 \%$ at a $15 \%$ increase in $g_{e}$. For pure biocomponent (B100) the decrease in the power output and torque reaches $12 \%$ (maximum $14 \%$ ) at a simultaneous

Table 2. Changes in the emission from the engine fueled with biocomponent fuels

Tabela 2. Zmiany emisji silnika zasilanego paliwami biokomponentowymi

\begin{tabular}{|l|c|c|c|c|}
\hline & PM & $\mathrm{HC}$ & $\mathrm{CO}$ & $\mathrm{NO}_{\mathrm{x}}$ \\
\hline ON & $\begin{array}{c}0.717 \\
\mathrm{~g} / \mathrm{kW} \cdot \mathrm{h}\end{array}$ & $\begin{array}{c}2.119 \\
\mathrm{~g} / \mathrm{kW} \cdot \mathrm{h}\end{array}$ & $\begin{array}{c}5.92 \\
\mathrm{~g} / \mathrm{kW} \cdot \mathrm{h}\end{array}$ & $\begin{array}{c}12.08 \\
\mathrm{~g} / \mathrm{kW} \cdot \mathrm{h}\end{array}$ \\
\hline B20 & $-4 \%$ & $-6 \%$ & $-4 \%$ & $-3 \%$ \\
\hline B50 & $-13 \%$ & $-21 \%$ & $-15 \%$ & $+8 \%$ \\
\hline B100 & $-19 \%$ & $-39 \%$ & $-24 \%$ & $+9 \%$ \\
\hline
\end{tabular}

increase of $g_{e}$ to $22 \%$ ( $23 \%$ ), whose main reason is a lower calorific value of B100 as compared to diesel fuel.

For the tested engine the range of medium engine speed on the operating characteristics is conspicuous - below this speed - we have a reduction (as compared to $\mathrm{ON}$ ) and above - an increase in the $\mathrm{NO}_{\mathrm{x}}$ emission (the lowest for B20). Above this engine speed a small increase in the concentration of $\mathrm{HC}$ and $\mathrm{CO}$ in the exhaust gas was observed for B50. For the rest a clear reduction of the concentration of $\mathrm{HC}$ and $\mathrm{CO}$ was observed for the entire range of engine loads and speeds.

\section{Fuels containing depolymer}

Diesel fuel depolymer mixtures have an influence on the engine operating parameters (Fig. 4) similar to that of biocomponent mixtures. wydaje się paliwo B20, dla którego zaobserwowano mniejsze poziomy emisji wszystkich toksycznych składników spalin, w porównaniu do emisji uzyskanych dla oleju napędowego, przy niewielkich zmianach parametrów pracy silnika $(\mathrm{M}$, N, $g_{e}-$ rys. 3).

Charakterystyczne wydaje się także paliwo B50, ponieważ wzrost powyżej $50 \%$ objętościowego udziału biokomponentu w paliwie powoduje osłabienie tendencji redukcji emisji PM, HC i CO, a także praktycznie - znikome przyrosty emisji tlenków azotu.

Dla paliw powyżej B30 radykalnie zmienia się charakter emisji $\mathrm{NO}_{x}$. Ponieważ rozpylenie paliwa $(\mathrm{B}>30)$ przebiega inaczej niż oleju napędowego (ze względu na różnice w lepkości obu paliw, dla $\mathrm{B}>30$ znacząco rośnie udział paliwa o dwukrotnie większej lepkości), więc powoduje to wzrost lokalnych temperatur spalania i sprzyja zwiększeniu emisji tlenków azotu (rys. 2). Prawdopodobnie wyższe temperatury spalania (obserwowany wzrost temperatur spalin) powodują, że sadza pierwotna zostaje $\mathrm{w}$ znacznym stopniu spalona $\mathrm{w}$ komorze spalania, co przy jednoczesnym uwolnieniu HC z cząstek stałych (wzrost emisji) powoduje, że adsorpcja fizyczna na powierzchni - już sadzy wtórnej - jest znacznie ograniczona. Ograniczenie to jest natury ilościowej, mniejsza ilość adsorbera (sadzy wtórnej) i substancji adsorbowanych, a także jakościowej - choćby z racji ograniczenia cyklizacji związków poliacetylenowych, które po odwodornieniu, przyjmują postacie wielopierścieniowych węglowodorów aromatycznych i ciężkich węglowodorów. Prawdopodobnie wyższe temperatury obiegu uniemożliwiają krzepnięcie fazy ciekłej i wcześniej uwalniają fazę gazową cząstek stałych PM, a aktywny tlen ma właściwości umożliwiające utlenianie węglowodorów nie tylko w masie spalin, ale także w masie samych cząstek stałych.

$\mathrm{W}$ tabeli 2 podano procentowe zmiany emisji (w odniesieniu do oleju napędowego, gdzie: ,„”" oznacza wzrost, a ,-, - zmniejszenie emisji) dla wybranych paliw biokomponentowych.

Z danych (dla wybranych paliw) przedstawionych na charakterystyce eksploatacyjnej silnika (rys. 3) wynika, że dla B20 (w porównaniu do ON) wzrost jednostkowego zużycia paliwa oraz zmniejszenie mocy i momentu rozwijanego przez silnik są niewielkie (rzędu kilku procent). Zdecydowanie pogarszają się parametry pracy silnika dla B50, spadek mocy i momentu o około $8 \%$ do $10 \%$ przy $15 \%$ wzroście ge. Dla czystego biokomponentu (B100) zmniejszenie mocy i momentu dochodzi do $12 \%$ (maksymalnie $14 \%$ ) przy jednoczesnym wzroście $g_{\mathrm{e}}$ do $22 \%$ (23\%), czego główną przyczyną jest przede wszystkim mniejsza wartość opałowa (B100) w porównaniu do oleju napędowego.

Dla badanego silnika znamienny jest zakres średniej prędkości obrotowej na charakterystyce eksploatacyjnej - poniżej tej prędkości - zmniejszenie (w porównaniu do ON), powyżej - wzrost stężeń $\mathrm{NO}_{\mathrm{x}}$ (najmniejszy dla B20). Powyżej tej prędkości obrotowej obserwowano również dla B50 niewielkie wzrosty stężeń $\mathrm{HC}$ i CO w spalinach. Dla pozostałych przypadków rejestrowano wyraźną obniżkę 
Based on the conducted engine tests we can confirm that the DEP20 fuel (Fig. 4) has the best parameters for which no drop in the engine power output, torque and overall efficiency were observed for low and medium loads. For engine loads and speeds greater than the engine speed of the maximum torque a slight deterioration of the engine parameters was observed with a maximum $5 \%$ drop in the engine load and speed of the maximum engine power.

A volumetric share of the depolymer in the mixture with diesel oil greater than $50 \%$ clearly results in a deterioration of the engine performance (decrease in the power output and torque reaching $15 \%$ including a drop in the engine efficiency) particularly under highest loads if the engine is fueled with pure depolymer (DEP100). The main reason for the observed phenomenon is lower density of the DEP100 depolymer fuel and its greater viscosity a compared to the density and viscosity of diesel fuel.

Additional cumulative effect is a much higher cetane number of the depolymer $(77,1)$ that significantly reduces the self-ignition delay [13] of a poorly atomized fuel mixture (greater viscosity) and causes a change in the nature of the ignition (particularly in the beginning of combustion) from kinetic to diffusive. The greater the load (greater fuel dose) the greater part of the combustion process continues in the non-homogenous mixture with a high share of the diffusion processes (simultaneous mixing of the fuel with air while the fuel injection lasts). The change of the course of the combustion process by

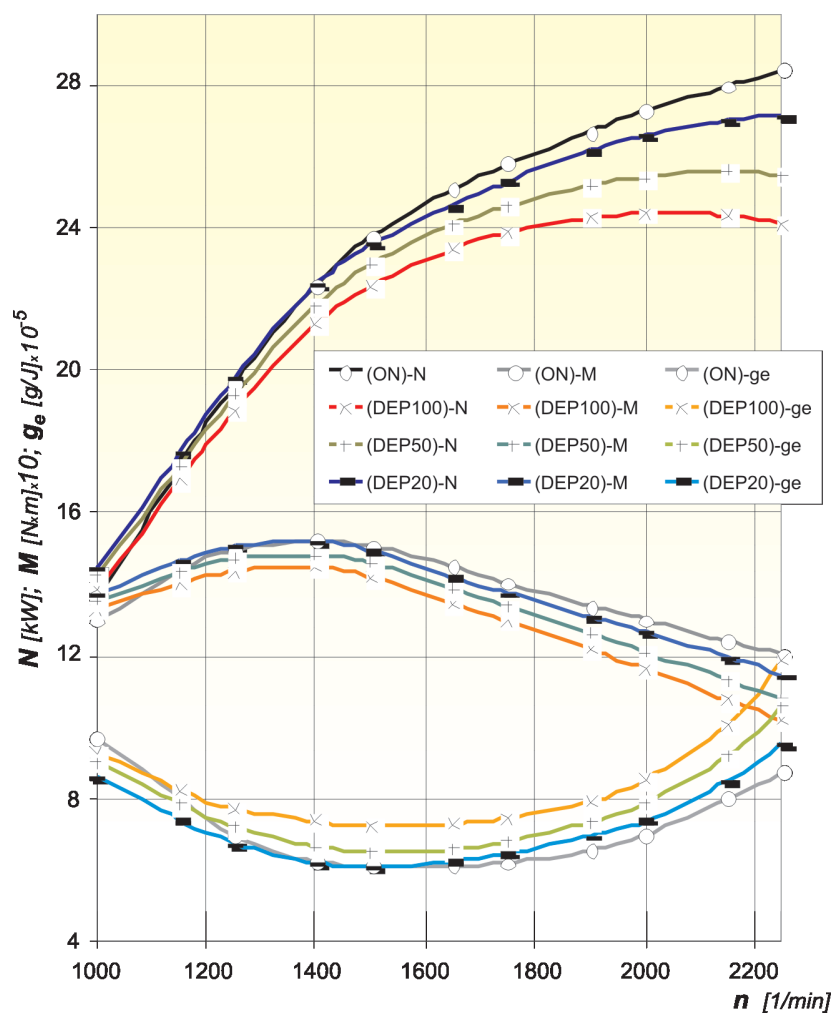

Fig. 4. External characteristics of the tested engine fueled with diesel fuel (ON) and depolymer fuels (DEP100, DEP50, DEP20)

Rys. 4. Charakterystyka zewnętrzna badanego silnika zasilanego olejem napędowym (ON) i paliwami depolimerowymi (DEP100, DEP50, DEP20)

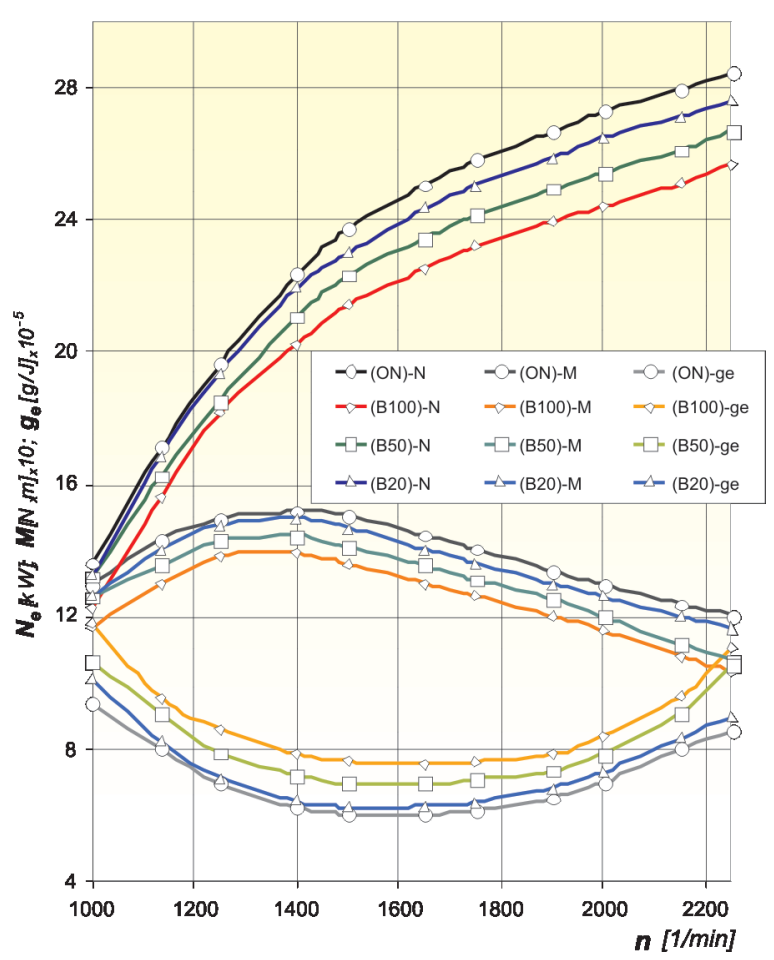

Fig. 3. External characteristics of the tested engine fueled with diesel fuel $(\mathrm{ON})$ and biofuels (B100, B50, B20)

Rys. 3. Charakterystyka zewnętrzna badanego silnika zasilanego olejem napędowym (ON) i biopaliwami (B100, B50, B20)

poziomów stężeń $\mathrm{HC}$ i CO dla całego zakresu obciążeń i prędkości obrotowych silnika.

\section{Paliwa $z$ dodatkiem depolimeru}

Mieszanki depolimerowe z olejem napędowym mają podobny wpływ na parametry eksploatacyjne silnika (rys. 4) jak mieszanki biokomponentowe.

Na podstawie przeprowadzonych badań silnikowych można stwierdzić, że najlepsze parametry eksploatacyjne wykazuje paliwo DEP20 (rys. 4), dla którego nie obserwowano spadku mocy i momentu oraz sprawności ogólnej silnika w zakresie małych i średnich obciążeń. Dla obciążeń i prędkości obrotowych wyższych od prędkości obrotowej maksymalnego momentu obserwowano nieznaczne pogorszenie parametrów pracy silnika, z maksymalnym 5-procentowym spadkiem w zakresie obciążeń i prędkości obrotowej maksymalnej mocy silnika.

Większy niż 50-procentowy objętościowy udział depolimeru w mieszaninie z olejem napędowym powoduje wyraźne pogorszenie osiągów silnika (spadek mocy i momentu dochodzący do $15 \%$ i spadek sprawności), zwłaszcza w zakresie najwyższych obciążeń, przy zasilaniu silnika czystym depolimerem (DEP100). Główną przyczyną obserwowanego zjawiska jest mniejsza gęstość paliwa depolimerowego DEP100 i jego większa lepkość w porównaniu do gęstości i lepkości stosowanego oleju napędowego.

Dodatkowy efekt kumulacyjny to znacznie większa liczba cetanowa depolimeru $(77,1)$, która powoduje wyraźne zmniejszenie opóźnienia samozapłonu [13] gorzej rozpylonej mieszaniny paliwowej (większa lepkość) i zmianę 
a clear limitation of the chemical part responsible for the self ignition delay (particularly cool and blue flame) [13] and a lower density of the DEP100 fuel results in a deterioration of the engine operating conditions and a significant drop in its efficiency.

Figure 5 presents a comparison of the emission of PM of an engine fueled with diesel fuel and fuels of different composition of diesel fuel, depolymer and pure depolymer $(100 \%)$. From the presented research material it results that in terms of the emission of PM the greatest $15 \%$ effect in limiting of this emission can be obtained for fuel mixtures containing $30-40 \%$ of the depolymer.

Most likely the major reason for a lower emission of PM is the elimination of its sulfate part of the insoluble fraction (thus a reduction in the total PM mass) as depolymer fuel (similarly to biofuel) does not contain sulfur. This takes place thanks to a greater content of sulfurless fuel in the PM formation process within the stage of secondary soot formation that most often originates from primary soot, in a time window that starts before the opening of the exhaust valve and lasts until the exhaust gas is fully evacuated. Under the conditions of rapidly reducing temperature resulting from the decompression and chilling of the exhaust gas, soot crystallites join in

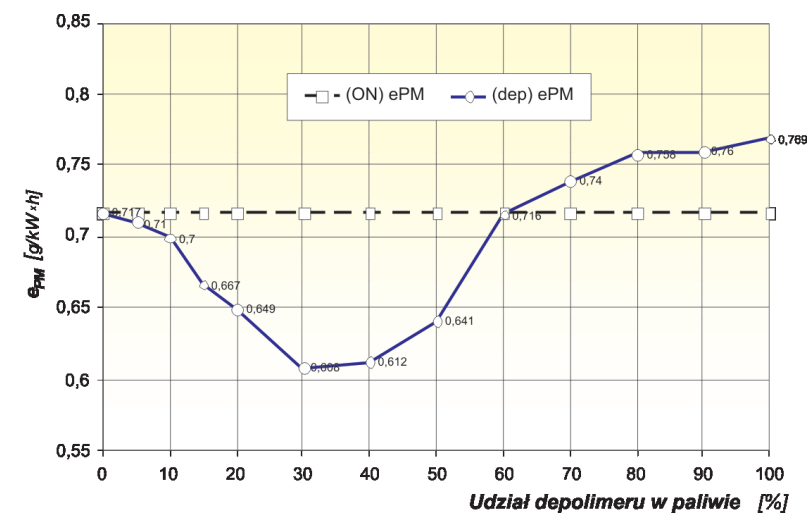

Fig. 5. Changes in the emission of PM triggered by different volumetric share of the depolymer in the fuel mixture

Rys. 5. Zmiany emisji cząstek stałych wywołane różnym objętościowym udziałem procentowym depolimeru $w$ mieszaninie paliwowej z olejem napędowym

aggregate and agglomerate structures and, additionally, these conditions facilitate low-temperature cyclization of polyacetylene compounds, that upon dehydrogenization assume forms of polycyclic aromatic hydrocarbons and heavy hydrocarbons. A drop in the temperature of the exhaust gas also facilitates freezing of the transient chemical structures in the stage of their partial oxidation or unfinished decomposition. These hydrocarbons in the gaseous or condensed state are adsorbed by the surface of aggregates and agglomerates of soot. Under these conditions a continuous restructuring of heavy hydrocarbons takes place along with a change of their state of concentration. Locally, hydrocarbons in the gaseous phase can condense and deposit on the surface of soot and other charakteru (zwłaszcza początku spalania) z kinetycznego na dyfuzyjny. Im większe obciążenie (większa dawka paliwa), tym większa część procesu spalania przebiega w mieszaninie niejednorodnej, z dużym udziałem procesów dyfuzji (jednoczesne mieszanie paliwa z powietrzem, częściowo podczas trwającego jeszcze wtrysku paliwa). Zmiana przebiegu procesu spalania przez wyraźne ograniczenie chemicznej części opóźnienia samozapłonu (zwłaszcza tzw. chłodnego i błękitnego płomienia) [13] i mniejsza gęstość paliwa DEP100 powodują w efekcie pogorszenie warunków pracy silnika i znaczny spadek jego sprawności.

Na rysunku 5 przedstawiono porównanie emisji cząstek stałych PM silnika zasilanego olejem napędowym i paliwami o różnym składzie komponentowym oleju napędowego i depolimeru oraz czystym $(100 \%)$ depolimerem. Z prezentowanego materiału badawczego wynika, że ze względu na emisję cząstek stałych największe 15-procentowe efekty w ograniczeniu tej emisji można uzyskać dla mieszanek paliwowych zawierających $30-40 \%$ depolimeru.

Prawdopodobnie główną przyczyną mniejszej emisji PM jest eliminacja siarczanowej części nierozpuszczalnej frakcji INSOL cząstek stałych (a tym samym redukcja całkowitej ilości masy cząstek), ponieważ paliwo depolimerowe (podobnie jak biopaliwo) nie zawiera w swoim składzie pierwiastkowym siarki. Odbywa się to dzięki większemu udziałowi bezsiarkowego paliwa $\mathrm{w}$ procesie formowania cząstek na etapie tworzenia sadzy wtórnej, która powstaje najczęściej z sadzy pierwotnej, w okresie który rozpoczyna się jeszcze przed otwarciem zaworu wylotowego i trwa aż do wydalenia spalin poza układ wylotowy. W warunkach szybko obniżającej się temperatury, wynikającej z rozprężania i ochładzania spalin, krystality sadzy łączą się w struktury agregatowe i aglomeratowe, a dodatkowo warunki te sprzyjają niskotemperaturowej cyklizacji związków poliacetylenowych, które po odwodornieniu przyjmują postacie wielopierścieniowych węglowodorów aromatycznych i ciężkich węglowodorów. Spadek temperatury spalin sprzyja także zamrażaniu przejściowych struktur chemicznych na etapie częściowego utlenienia lub niedokończonego ich rozpadu. Węglowodory te w stanie gazowym lub skondensowanym są adsorbowane przez powierzchnie agregatów i aglomeratów sadzy. W tych warunkach występuje ciągła przebudowa struktur ciężkich węglowodorów i zmiana ich stanu skupienia. Lokalnie węglowodory w fazie gazowej mogą kondensować i osiadać na powierzchniach sadzy i innych cząstek (np. siarczany i azotany) lub odwrotnie - parować i oddzielać się od tych cząstek.

W składzie strukturalnym cząstek stałych (przy zasilaniu olejem napędowym) dominuje forma siarczanowa. Siarka zawarta w paliwie prawie całkowicie utlenia się w procesie spalania do $\mathrm{SO}_{2} \mathrm{i}$ w większości w takiej formie jest usuwana ze spalinami; pozostała część podlega konwersji do $\mathrm{SO}_{3}$, tym większej, im wyższe są temperatura i stężenie tlenu w spalinach. Trójtlenek siarki przez wysokie powinowactwo do wody (w reakcji egzotermicznej tworzy się kwas siarkowy) tworzy siarczany adsorbowane przez sadzę silnikową, powodując przyrost nierozpuszczalnej frakcji INSOL cząstki stałej. 
particles (sulfates and nitrates) or vice versa - get in pairs and separate from these particles.

In the structural composition of particulate matter (when fueled with diesel fuel) the sulfate form is the dominant one. The sulfur contained in the fuel almost entirely oxidizes to $\mathrm{SO}_{2}$ in the combustion process and mostly in this form is eliminated with the exhaust gas; the outstanding part is converted to $\mathrm{SO}_{3}$, more intensely if the temperature and oxygen concentration in the exhaust gas are higher. $\mathrm{SO}_{3}$ through its high affinity to water (in an exothermal reaction sulfuric acid forms) form sulfates adsorbed by the engine soot leading to an increment of the insoluble fraction (INSOL) of the particulate matter.

As a result of the conducted microscopic research (Fig. 6) clear differences in the structure of the PM coming from a).

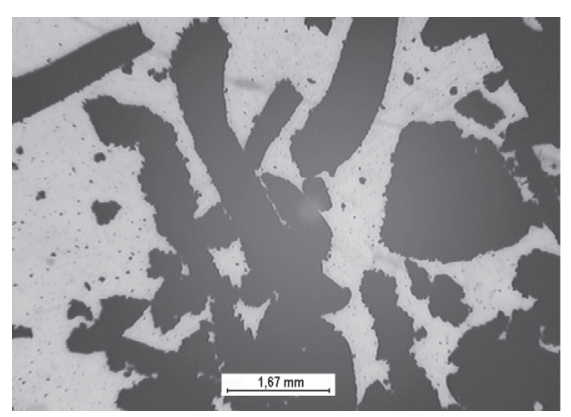

b).

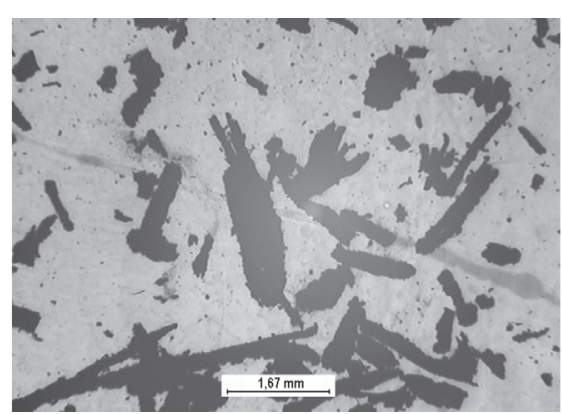

W wyniku przeprowadzonych badań mikroskopowych (rys. 6) stwierdzono wyraźne różnice w strukturze cząstek stałych pochodzących ze spalania paliw ON, B100, D100 i ich mieszanin.

Cząstki stałe PM pochodzące ze spalania czystego biopaliwa i czystego depolimeru są kilka do kilkanaście razy mniejsze od cząstek pochodzących z oleju napędowego. Prawdopodobnie główną przyczyną ich mniejszych wymiarów jest eliminacja siarczanowej części frakcji INSOL cząstek, ponieważ biopaliwo i depolimer nie zawierały w swoim składzie pierwiastkowym siarki.

Przeprowadzone badania wykazały, że większy niż $60 \%$ udział depolimeru w paliwie powoduje wzrost emisji cząstek stałych (rys. 5), osiągając 7-procentowy wzrost emisji dla czystego depolimeru (DEP100). Prawdopodobną przyczyną

c).

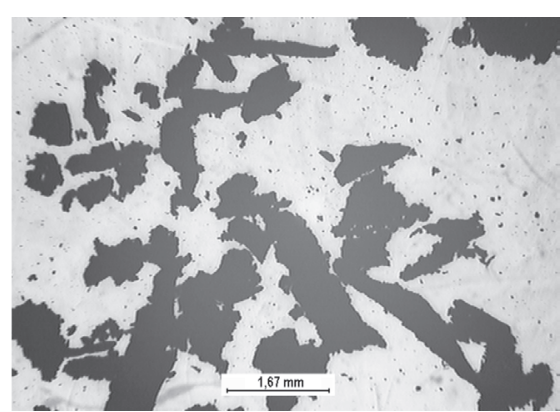

Fig. 6. Macrostructures of PM,- comparison- (microscopic) for fuels: a) B100), c) depolymer diesel fuel (ON), b) biocomponent RME ( (D100) Rys. 6. Makrostruktury cząstek stałych - porównanie - (optyczny mikroskop pomiarowy) dla paliw: a) olej napędowy (ON), b) biokomponent RME (B100), c) depolimer (D100)

the combustion of ON, B100, D100 and their mixtures have been observed.

Particulate matter generated by the combustion of pure biofuel and pure depolymer is several times smaller than that generated in the combustion of diesel fuel. Most likely the main reason for its smaller size is the elimination of the sulfate INSOL fraction as biofuel and the depolymer did not contain any sulfur.

The conducted research has shown that a share of the depolymer in the fuel greater than $60 \%$ results in a growth of the PM emission (Fig. 5) reaching a $7 \%$ increase for pure depolymer (DEP100). The most likely reason for this growth is the growing share of the fuel of lower density in the combustion process - a share that outruns the advantageous influence of lack of sulfur in the fuel (eliminating the INSOL fraction of particulate matter) that limits the emission of PM as compared to diesel fuel.

Table 3 presents percentage changes of the emissions (as compared to diesel fuel) for selected depolymer fuels and Fig. 7 presents a comparison of the emission from the engine fueled with selected components of diesel fuel and the depolymer.

\section{Mixtures of bio-depolymer fuels}

Figure 8 presents a comparison of the emissions from an engine fueled with diesel fuel and mixtures of diesel fuel and selected contents of biofuel and the depolymer tego wzrostu emisji jest rosnący udział w procesie spalania większej ilości paliwa o mniejszej gęstości, przewyższający korzystny wpływ braku siarki w paliwie (eliminującego frakcję INSOL cząstek stałych), ograniczający emisję cząstek w porównaniu do oleju napędowego.

$\mathrm{W}$ tabeli 3 podano procentowe zmiany emisji (w odniesieniu do oleju napędowego) dla wybranych paliw depolimerowych, a na rys. 7 przedstawiono porównanie emisji silnika zasilanego wybranymi komponentami oleju napędowego i depolimeru.

\section{Mieszanki paliw bio-depolimerowych}

Na rysunku 8 przedstawiono porównanie emisji silnika zasilanego olejem napędowym i mieszankami o wybranej zawartości biopaliwa i depolimeru, a na rys. 9-porównanie emisji cząstek stałych silnika zasilanego paliwem o pełnym spektrum badanych komponentów biopaliwa i depolimeru.

Na rysunku 10 przedstawiono wyniki badań parametrów eksploatacyjnych silnika zasilanego komponentem paliwowym będącym mieszaniną (50/50) paliwa B20 i DEP20.

O wyborze składu komponentowego mieszaniny zadecydowały następujące względy:

- dla B20, dla którego zaobserwowano mniejsze poziomy emisji wszystkich toksycznych składników spalin w porównaniu do emisji uzyskanych dla oleju napędowego, przy niewielkich zmianach parametrów pracy silnika $(\mathrm{M}$, $\mathrm{Ne}, \mathrm{g}_{\mathrm{e}}$ ), 
Table 3. Changes in the emissions of an engine fueled with selected depolymer fuels

Tabela 3. Zmiany emisji silnika zasilanego wybranymi paliwami depolimerowymi

\begin{tabular}{|l|c|c|c|c|}
\hline & $\mathrm{PM}$ & $\mathrm{HC}$ & $\mathrm{CO}$ & $\mathrm{NO}_{\mathrm{x}}$ \\
\hline ON & $\begin{array}{c}0.717 \\
\mathrm{~g} / \mathrm{kW} \cdot \mathrm{h}\end{array}$ & $\begin{array}{c}2.119 \\
\mathrm{~g} / \mathrm{kW} \cdot \mathrm{h}\end{array}$ & $\begin{array}{c}5.92 \\
\mathrm{~g} / \mathrm{kW} \cdot \mathrm{h}\end{array}$ & $\begin{array}{c}12.08 \\
\mathrm{~g} / \mathrm{kW} \cdot \mathrm{h}\end{array}$ \\
\hline DEP20 & $-9 \%$ & $+3 \%$ & $+7 \%$ & $+13 \%$ \\
\hline DEP50 & $-11 \%$ & $+2 \%$ & $+17 \%$ & $+1 \%$ \\
\hline DEP100 & $-7 \%$ & $+6 \%$ & $+34 \%$ & $-9 \%$ \\
\hline
\end{tabular}

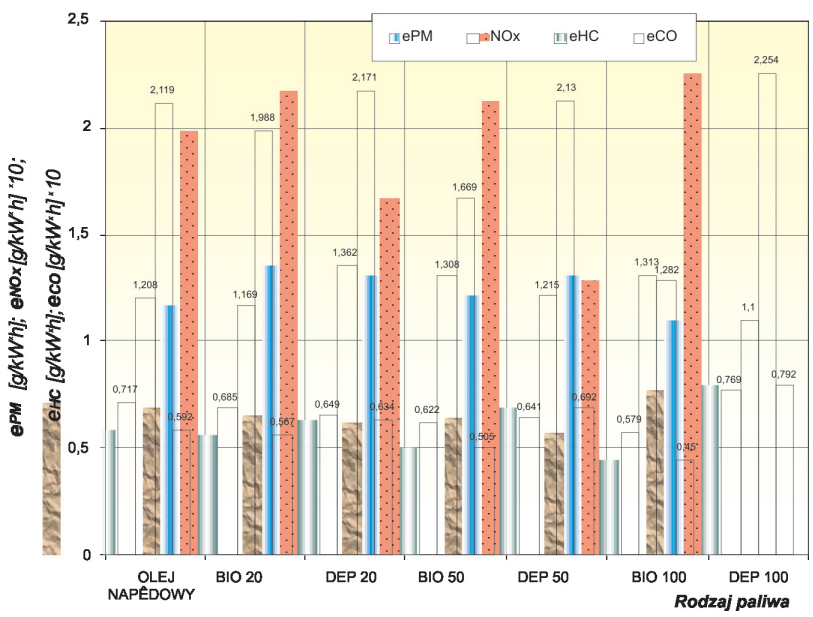

Fig. 8. Comparison of the emissions from an engine fueled with diesel fuel, biofuel and the depolymer

Rys. 8. Porównanie emisji silnika zasilanego olejem napędowym, biopaliwem i depolimerem

while Fig. 9 - a comparison of the emissions of PM from an engine fueled with a full spectrum of the tested biofuels and depolymers.

Figure 10 presents the results of the tests of the operating parameters of an engine fueled with a fuel mixture of B20 and DEP20 (50/50).

The mixture composition was selected because:

- in the case of B20, a lower emission of all exhaust components was observed as compared to the emissions obtained for diesel fuel, at negligible changes of the engine operating parameters $\left(\mathrm{M}, \mathrm{Ne}, \mathrm{g}_{\mathrm{e}}\right)$,

- in the case of DEP20 - a lower impact on the PM emission reduction was observed against DEP30, but DEP20 showed better operating parameters.

From the presented research material it results that the application of $(\mathrm{BIO}+\mathrm{DEP}) / 20$ does not deteriorate the operating parameters of the engine particularly in medium engine loads and speeds. The most likely reason for this phenomenon is the compensative influence of the significantly lower density of DEP20 that compensates the much greater density and viscosity of B20, which makes both these parameters close to those of diesel fuel. Important is the increase in the cetane number of the mixture thanks to which the changing of the nature of the combustion process positively influences its effects and results in a reduction of the exhaust emissions

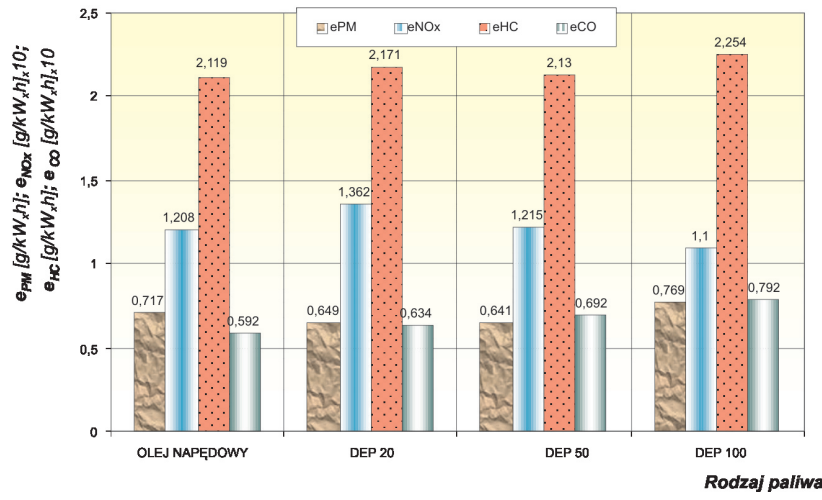

Fig. 7. Changes in the engine emissions caused by different share of the depolymer in the fuel mixture

Rys. 7. Zmiany emisji silnika spowodowane różnym udziałem depolimeru w mieszaninie z olejem napędowym

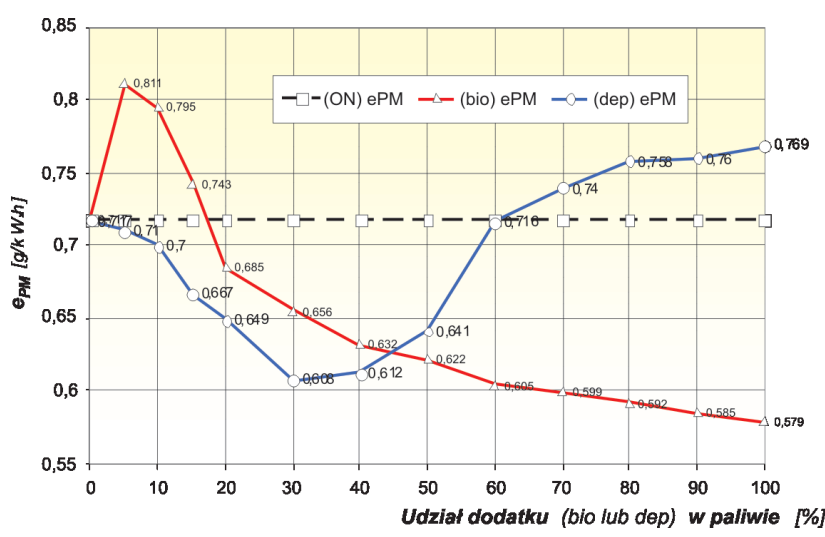

Fig. 9. Comparison of the emission of PM from an engine fueled with a fuel of different content of biofuel and the depolymer

Rys. 9. Porównanie emisji cząstek stałych silnika zasilanego paliwem o różnym składzie komponentowym biopaliwa i depolimeru

- dla DEP20 przyjęto komponent o mniejszym wpływie w ograniczeniu emisji cząstek stałych niż DEP30, ale wykazujące najlepsze parametry eksploatacyjne.

Z prezentowanego materiału badawczego wynika, że zastosowanie paliwa (BIO+DEP)/20 nie pogarsza parametrów eksploatacyjnych silnika, zwłaszcza w zakresie średnich obciążeń i prędkości obrotowych. Prawdopodobną przyczyną tego zjawiska jest kompensacyjny wpływ znacznie mniejszej gęstości DEP20 niwelujący znacznie większą gęstość i lepkość B20, przez co oba te parametry zbliżone są do wartości charakterystycznych dla oleju napędowego. Dominujące znaczenie ma prawdopodobnie wzrost liczby cetanowej mieszaniny, dzięki czemu zmiana charakteru procesu spalania pozytywnie oddziałuje na jego efekty i powoduje ograniczenie emisji toksycznych składników spalin (oprócz $\mathrm{NO}_{\mathrm{x}}$ - na niezmiennym poziomie), które zaprezentowano $\mathrm{w}$ tabeli $4 \mathrm{i}$ na rys. 11.

\section{Wnioski}

Na podstawie przeprowadzonych badań i ich analizy można sformułować następujące wnioski:

- Biokomponenty i depolimery paliwowe $\mathrm{z}$ racji swojej obecności w procesie spalania uczestniczą w procesie for- 
(except $\mathrm{NO}_{x},-$ which remains on the same level) as presented in Table 4 and Fig. 11.

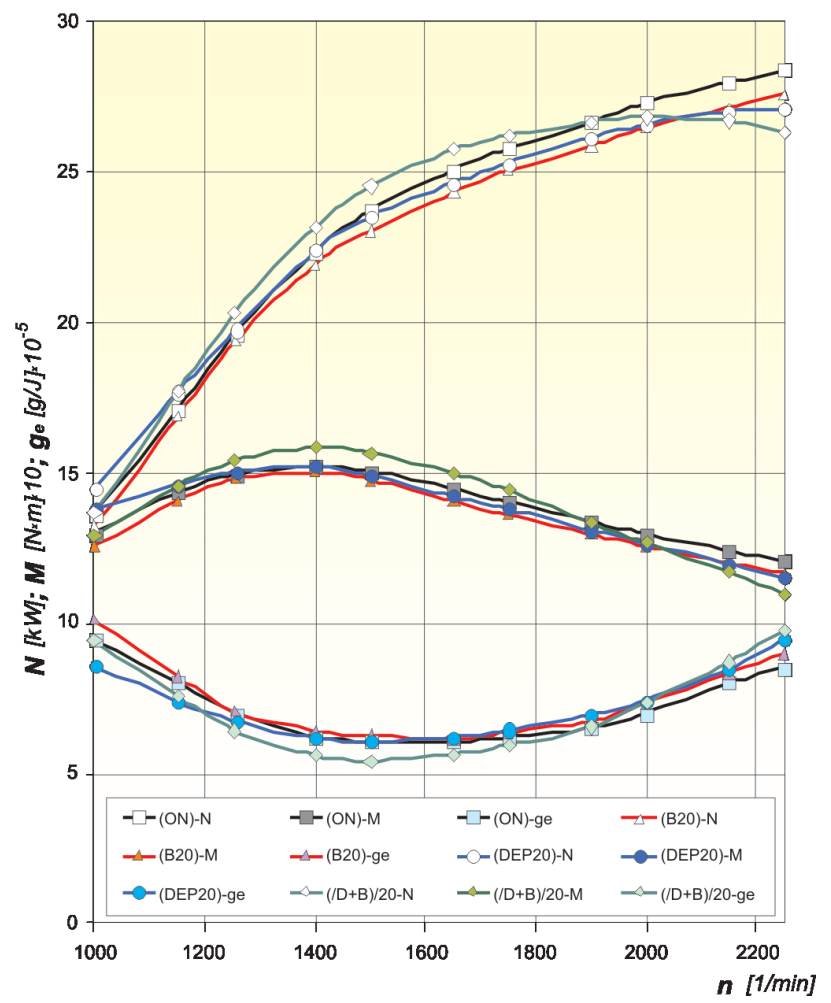

Fig. 10. Comparison of the characteristics of the tested engine fueled with diesel fuel (ON), biofuel B20, the DEP20 depolymer and their mixtures $(\mathrm{BIO}+\mathrm{DEP}) / 20$

Rys. 10. Porównanie charakterystyk badanego silnika zasilanego olejem napędowym $(O N)$, biopaliwem B20, depolimerem DEP20 i ich mieszani$n a(B I O+D E P) / 20$

\section{Conclusions}

Based on the performed research and its analysis we can formulate the following conclusions:

- Fuel biocomponents and depolymers due to their role in the combustion process participate in the formation of primary soot as a final product of high temperature fuel decomposition and secondary soot formed under the conditions of rapidly dropping temperature in the final phase of oxidation in the combustion chamber. They have a varied influence on the structure of the particles caused by changing the shares of the soluble and insoluble parts of the particle, thus influencing the efficiency of the particle mass reduction.

- A reduction in the PM emission level in the exhaust gas of a diesel engine by the tested fuel biocomponents and depolymers is most likely caused by the reduction of the share of the insoluble fraction (INSOL) in the total mass of the emitted PM.

- Above $20 \%$ of the share of the biocomponent or the depolymer in the mixture gives significant effects in the reduction of the PM emission. The best performance in this respect was obtained for pure rapeseed oil methyl ester.
Table 4. Changes in the emissions from an engine fueled with biodepolymer fuels and their mixtures

Tabela 4. Zmiany emisji silnika zasilanego paliwami bio-depolimerowymi i ich mieszanina

\begin{tabular}{|l|c|c|c|c|}
\hline & $\mathrm{PM}$ & $\mathrm{HC}$ & $\mathrm{CO}$ & $\mathrm{NO}_{\mathrm{x}}$ \\
\hline $\mathrm{ON}$ & $\begin{array}{c}0.717 \\
\mathrm{~g} / \mathrm{kW} \cdot \mathrm{h}\end{array}$ & $\begin{array}{c}2.119 \\
\mathrm{~g} / \mathrm{kW} \cdot \mathrm{h}\end{array}$ & $\begin{array}{c}5.92 \\
\mathrm{~g} / \mathrm{kW} \cdot \mathrm{h}\end{array}$ & $\begin{array}{c}12.08 \\
\mathrm{~g} / \mathrm{kW} \cdot \mathrm{h}\end{array}$ \\
\hline $\mathrm{B} 20$ & $-4 \%$ & $-6 \%$ & $-4 \%$ & $-3 \%$ \\
\hline $\mathrm{DEP} 20$ & $-9 \%$ & $+3 \%$ & $+7 \%$ & $+13 \%$ \\
\hline$(\mathrm{B}+\mathrm{DEP}) / 20$ & $-15 \%$ & $-15 \%$ & $-7 \%$ & $0 \%$ \\
\hline
\end{tabular}

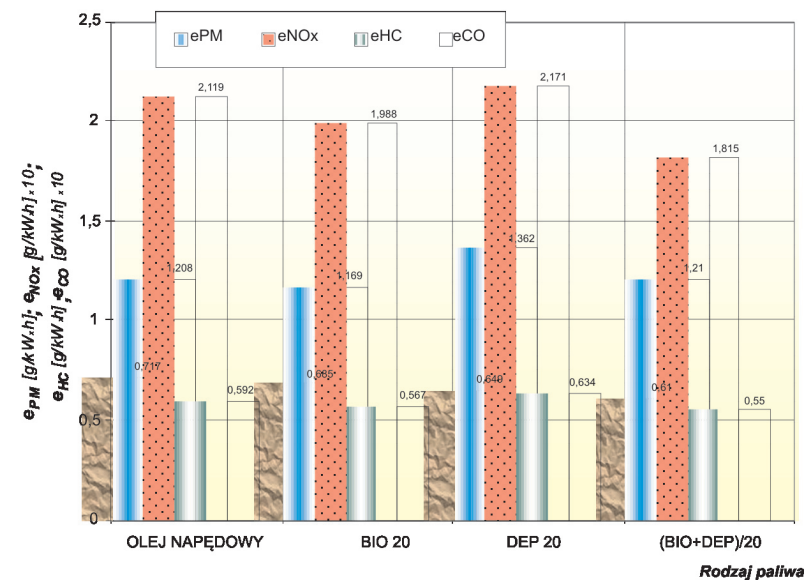

Fig. 11. Comparison of the emission from an engine fueled with diesel fuel, biofuel B20, the DEP20 depolymer and their mixtures $(\mathrm{BIO}+\mathrm{DEP}) / 20$

Rys. 11. Porównanie emisji silnika zasilanego olejem napędowym, biopaliwem B20, depolimerem DEP20 i ich mieszanina $(B I O+D E P) / 20$

mowania tzw. sadzy pierwotnej jako finalnego produktu wysokotemperaturowego rozpadu paliwa i sadzy wtórnej powstającej w warunkach szybko obniżającej się temperatury w końcowej fazie procesu utleniania w komorze spalania. Wpływają one różnie na strukturę cząstek przez zmianę udziałów części rozpuszczalnej i nierozpuszczalnej cząstki, a więc $\mathrm{w}$ rezultacie na efektywność redukcji masy cząstek.

- Ograniczenie poziomu emisji cząstek stałych w spalinach silnika o ZS przez badane biokomponenty i depolimery paliwowe prawdopodobnie odbywa się głównie dzięki redukcji udziału frakcji nierozpuszczalnej INSOL w całkowitej masie emitowanych cząstek stałych.

- Powyżej 20 \% udziału biokomponentu lub depolimeru w mieszaninie z olejem napędowym daje znaczące efekty w ograniczeniu emisji cząstek stałych. Największe efekty w tym względzie uzyskano dla czystego estru metylowego oleju rzepakowego.

- Dodatek 30 - 40 \% depolimeru do oleju napędowego redukuje emisję PM na poziomie $15 \%$. Większy niż 60 $\%$ udział depolimeru w paliwie powoduje wzrost emisji, maksymalny dla czystego DEP100, w porównaniu do emisji przy spalaniu oleju napędowego.

- Cząstki stałe pochodzące ze spalania oleju napędowego mają strukturę aglomeratową z dużym udziałem krzepnącej fazy ciekłej, natomiast cząstki stałe pochodzące ze 
- An addition of $30-40 \%$ depolymer to the diesel fuel reduces the PM mass by $15 \%$. A share of the depolymer in the fuel greater than $60 \%$ results in a growth of the PM emission, which is maximum for pure DEP100 as compared to the emission when fueled with diesel fuel.

- PM generated in the combustion of diesel fuel has an agglomerate structure with a large share of the liquid phase while the PM generated in the combustion of the biocomponent and the depolymer has an aggregate structure with small additions of agglomerates (liquid phase not observed). The differences in the PM size are considerable. The PM from the combustion of diesel fuel is several times larger than the PM generated in the combustion of biocomponents or depolymers.

- The application of (BIO+DEP)/20 does not deteriorate the engine operating parameters - particularly in the range of medium engine loads and speeds.

- The change of the nature of the combustion process when fueled with $(\mathrm{BIO}+\mathrm{DEP}) / 20$ (most likely caused by the compensative influence of viscosity and density and an increase in $\mathrm{CN}$ ) results in a reduction of the exhaust emissions $-15 \% \mathrm{PM}$ and $\mathrm{HC}, 7 \% \mathrm{CO}$, with $\mathrm{NO}_{\mathrm{x}}$ remaining on the same level. spalania biokomponentu i depolimeru mają już strukturę agregatową z niewielkimi wtrąceniami aglomeratów, w której nie zaobserwowano wyraźnej fazy ciekłej. Różnice w wielkościach cząstek są znaczne. Cząstki PM ze spalania oleju napędowego są od kilku do kilkunastu razy większe od cząstek stałych, których źródłem są biokomponenty lub depolimery.

- Zastosowanie paliwa (BIO+DEP)/20 nie pogarsza parametrów eksploatacyjnych silnika - zwłaszcza w zakresie średnich obciążeń i prędkości obrotowych.

- Zmiana charakteru procesu spalania przy zasilaniu (BIO+ DEP)/20 (prawdopodobnie przez kompensacyjny wpływ lepkości i gęstości, a zwłaszcza wzrost LC) powoduje również ograniczenie emisji toksycznych składników spalin $-15 \%$ PM i HC, $7 \%$ CO, przy $\mathrm{NO}_{x}$ - na niezmiennym poziomie.

\section{Bibliography/Literatura}

[1] Baczewski K., Kołdoński T.: Paliwa do silników o zapłonie samoczynnym. WKiŁ, Warszawa 2004.

[2] Budzyńska-Józwiak A., Sosnowska-Maciukiewicz L., Szumacher S., Swat M.: Zastosowanie hydrorafinowanego destruktu z krakingu odpadowych tworzyw sztucznych jako bazy komponentów paliw ciekłych. Problemy Eksploatacji, 3/2009.

[3] Chłopek Z:: Ocena emisji zanieczyszczeń z silników spalinowych zasilanych paliwem biogazowym. Combustion Engines/ Silniki Spalinowe 1/2012.

[4] Darkowski A.: Katalityczny kraking odpadowych poliolefin na katalizatorach zeolitowych do paliw silnikowych. Materiały XIII Forum zeolitowego, Polańczyk 2006.

[5] Darkowski A., Swat M.: Catalytic cracking of polyolefines waste to diesel oil and gasoline. Problemy Eksploatacji 4/2006.

[6] Kodera Y., Ishihara Y.: Novel process for recycling waste plastics to fuel gas using a moving-bed reactor. Energy \& Fuels 20/2006.

[7] Łuksa A., Sobczak M., Gos M., Wojcieszak P., Krzemińska M., Stępień A., Dębek C.: Wykorzystanie ciekłych frakcji z termodestrukcji odpadów polimerowych jako komponentów paliw węglowodorowych. Przem. Chem. 87/2008.

[8] Merkisz J., Kozak M., Pielecha J., Andrzejewski M.: Wpływ zastosowania mieszanin oleju napędowego i RME o różnym składzie na emisję cząstek stałych. Combustion Engines/ Silniki Spalinowe 1/2012.

[9] Niewczas A., Gil L., Ignaciuk P.: Wybrane aspekty stosowania biopaliw na przykładzie estrów metylowych oleju lnianki. Combustion Engines/Silniki Spalinowe 1/2012

[10] Sarbak Z.: Kataliza w ochronie środowiska. 2004.

[11] Szlachta Z.: Zasilanie silników wysokoprężnych paliwami rzepakowymi. WKiŁ, Warszawa 2002.

[12] Tinaut V.F., Melgar A., Briceno Y., Horrillo A.: Performance of vegetable derived fuels in diesel engine vehicles. Combustion Engines/Silniki Spalinowe 2/2005.

[13] Zabłocki M.: Wtrysk i spalanie paliwa w silnikach wysokoprężnych. WKiŁ, Warszawa 1976.

[14] Polska Norma. Paliwa do pojazdów samochodowych, oleje napędowe, PN-EN 590.
Marek Swat, DEng. - Doctor in the Institute for Sustainable Technologies National Research Institute in Radom.

Dr inż. Marek Swat - adiunkt w Instytucie Technologii Eksploatacji - Państwowym Instytucie Badawczym w Radomiu

e-mail: marek.swat@itee.radom.pl

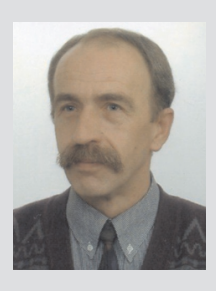

Krzysztof Madej, DEng. - Doctor in the Institute for Sustainable Technologies National Research Institute in Radom.

Dr inż. Kszysztof Madej - adiunkt w Instytucie Technologii Eksploatacji - Państwowym Instytucie Badawczym w Radomiu.

e-mail: krzysztof.madej@itee.radom.pl 